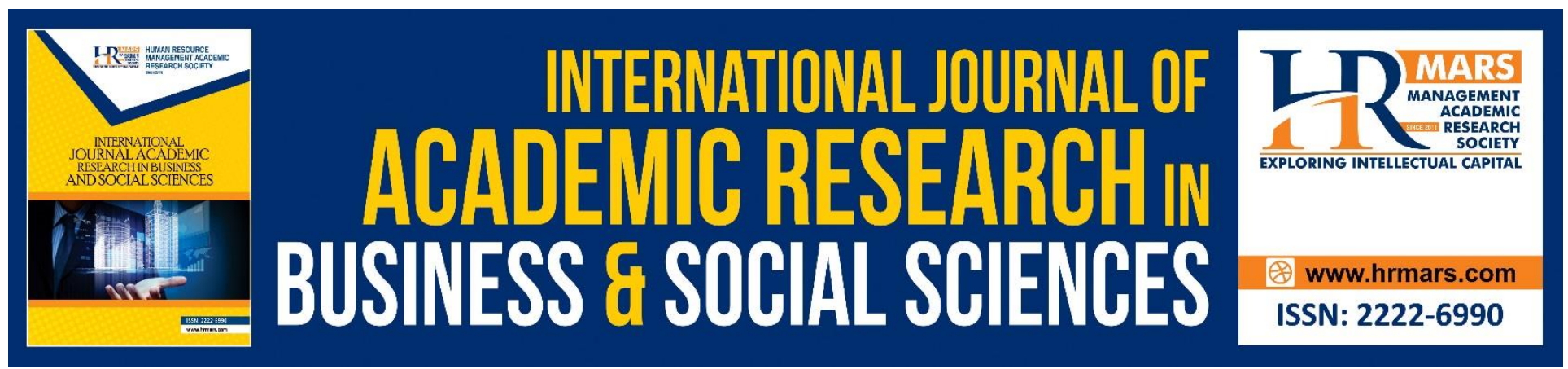

\title{
Assessment of Cross Cultural Communication Strategy with Employees' Performance in Selected Multinationals in South East Nigeria
}

Onuoha, Charity C. John-Onuoha, Emmanuel Ifeanyi Thaddeus, Thompson Saviour

To Link this Article: http://dx.doi.org/10.6007/IJARBSS/v8-i12/5158 DOI: 10.6007/IJARBSS/v8-i12/5158

Received: 24 Oct 2018, Revised: 06 Dec 2018, Accepted: 21 Dec 2018

Published Online: 26 Dec 2018

In-Text Citation: (Onuoha, John-Onuoha, \& Thaddeus, 2018)

To Cite this Article: Onuoha, C. C., John-Onuoha, E. I., \& Thaddeus, T. S. (2018). Assessment of Cross Cultural Communication Strategy with Employees' Performance in Selected Multinationals in South East Nigeria. International Journal of Academic Research in Business and Social Sciences, 8(12), 1121-1136.

Copyright: (c) 2018 The Author(s)

Published by Human Resource Management Academic Research Society (www.hrmars.com)

This article is published under the Creative Commons Attribution (CC BY 4.0) license. Anyone may reproduce, distribute, translate and create derivative works of this article (for both commercial and non-commercial purposes), subject to full attribution to the original publication and authors. The full terms of this license may be seen

at: http://creativecommons.org/licences/by/4.0/legalcode

Vol. 8, No. 12, 2018, Pg. 1121 - 1136

http://hrmars.com/index.php/pages/detail/IJARBSS

JOURNAL HOMEPAGE

Full Terms \& Conditions of access and use can be found at http://hrmars.com/index.php/pages/detail/publication-ethics 


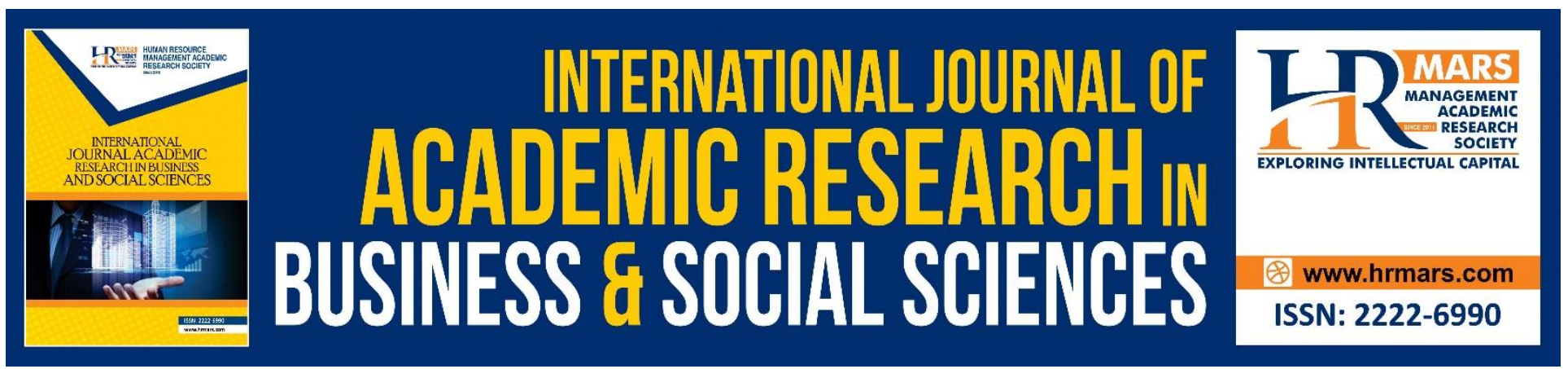

\title{
Assessment of Cross Cultural Communication Strategy with Employees' Performance in Selected Multinationals in South East Nigeria
}

\author{
Onuoha, Charity C. (Ph.D.) \\ Department of Business Administration, Faculty of Management Sciences, \\ Enugu State University of Science and Technology (ESUT), Enugu, Enugu State, Nigeria \\ John-Onuoha, Emmanuel Ifeanyi \\ Faculty of Commerce, Law and Management \\ University of the WITWATERSRAND, Johannesburg, South Africa. \\ Thaddeus, Thompson Saviour \\ Department of management, Faculty of business administration \\ University of Nigeria, Enugu campus
}

\begin{abstract}
This paper focuses on assessment of Cross Cultural communication strategy on Employees performance in Selected Multinationals in South East, Nigeria. The objectives which guided the study were a to ascertain the effect of adopting cross cultural communication strategy on employee performance of selected multinational companies and examine the effect of cross cultural religious tolerance on employee performance. A five point Likert scale-type questionnaire was constructed, and administered among the staff of the selected multinational companies in the South East Nigeria manually. The sample size of 313 was obtained from the population. The hypotheses were tested using simple linear regression statistical tools. The results of the analyses showed that adoption of cross cultural communication strategy positively affects employee performance of selected multinational companies in the South East of Nigeria $(r=.930 ; f=1474.049 ; t=38.393 ; p=.00$ ). Implementation of cross-cultural religious tolerance positively affects employee performance of selected multinational companies in the South East of Nigeria $(r=.938 ; f=276.425 ; t=16.626 ; p=$ $.00)$. The study concluded that; cross-cultural communication strategy and religion tolerance influence employees' performance of multinational companies'. It was recommended that; Management of various multinationals should develop a policy framework that will encourage the
\end{abstract}


INTERNATIONAL JOURNAL OF ACADEMIC RESEARCH IN BUSINESS AND SOCIAL SCIENCES

Vol. 8, No. 12, Dec, 2018, E-ISSN: 2222-6990 @ 2018 HRMARS

diverse cultural communication especially as regards to the operational area of the multinational; the employees of an organization should see diverse religion within the organization as ane hence creating an atmosphere that will improve individual and organizational performance.

Keywords: Communication Strategy, Employees' Performance, Cross Cultural, Religious Tolerance

\section{Introduction}

The adverse change in technological advancement which leads to economic development, the economy has become more global as diverse workforce are working and communicating across culture. However, the organizational management philosophy, organizational models and management practices are undergoing changes. Thus, Technological development has changed the flow of information, communication and expertise around the world; it leads to the growing numbers of multinational corporations across culture (Schmidt et al., 2007). Multinational corporations (MNCs) are playing a significant role in the world economy. Its help established domestic and international markets that can provide import and export productions, joint ventures and business contracts. Multinational organizations help to improve the process of globalization also use global resources to build international industry alliances (Schmidt et al., 2007). International connectedness is a key measure of globalization in international business; as diverse people work and communicate across culture thereby improving organizational performance.

Cross-culture is the interaction between two or more different groups that have different background and culture. Cultural differences are normally listed as dissimilar language, background, perceptions and mentalities (Ling et al., 2007). Cross-cultural management explains the attitude of people in organizations all over the world and shows people how to work in organizations with workers and client populations who are from different cultures (Ihugba, Odii, \& Njoku, 2013). Cultural management issue is a very much related topic of sociology or political science field. The managerial implication of cross-cultural management appeared to be a challenge for global firms when they are extending their businesses as a result of rapid pace of globalization (He \& Liu, 2010). But recent increases in low-cost labor and accelerated professional mobility have increased the room for debate on the impact of cultural diversity in workplace, which led researchers to study and advance their research in the field of cultural diversity. Despite this irreversible trend, only recently have researchers begun to seriously study the diversity management at firm level (Cox \& Beale, 1997).

The concept of diversity encompasses reception and respect. It means understanding that each personality is unique, and recognizing our individual differences. These can be along the dimensions of race, ethnicity, gender, sexual orientation, socio-economic status, age, physical abilities, religious beliefs, political beliefs, or other ideologies. These can be along the dimensions of race, ethnicity, gender, sexual orientation, socio-economic status, age, physical abilities, religious beliefs, political beliefs, or other ideologies (Mathis and Jackson, 2007). When these unique individual differences are understood by management of Multinational Corporation there will be a free flow of communication among workers.

Apparently, these unique individual differences are also considered as the major barriers in the crosscultural communication ineffectiveness. In a certain culture environment a certain way of communication is conducted; the big myth of intercultural communication is people expect others to 
do as they do; the disappointment would result in failure in cross-cultural communication. Cross cultural communication is a recognition process that people from different cultures reach their goals by trying to understand each other's cultural awareness (Schmidt et al., 2007).

Culture influences every single aspect of communication, and communication is influenced by organizational, cultural and national culture at the same time. And culture plays the most important role in communication because of its dominating influence on people's thinking and behavior except for individual differences. Consequently the main challenge for cross-cultural communication is how people from one cultural background would react to other cultures when there are cultural conflicts. Base on this challenge this paper seeks to assess Cross Cultural communication strategy on Employees performance in Selected Multinationals in South East, Nigeria.

\section{Objectives of the Study}

I. Ascertain the effect of adopting cross cultural communication strategy on employee's performance of selected multinational in South East Nigeria.

II. Examine the effect of cross cultural religious tolerance on employee performance of selected multinational companies in the South East Nigeria.

\section{Research Question}

I. What is the effect of Adopting of cross cultural communication strategy on organizational performance of selected multinational companies in the South East Nigeria?

II. What is the effect of cross cultural religious tolerance on employee performance of selected multinational companies in the South East Nigeria?

\section{Literature Review}

\section{Cross Cultural Communication strategy and Employees Performance}

Hooker (2008) opines that communication is a fundamental element in business, because business is a linking activity. Goods and services are produced and exchanged by means of close coordination of many individuals, sometimes within a particular village or city, and sometimes across global distances. Coordination of this nature requires concentrated communication. Complex product specifications and production schedules have to be mutually understood, and complex deals between trading partners must be negotiated. Communication styles differ enormously across the globe, and these add to an astounding variety of business styles. As mentioned by Hooker, the single most useful concept for understanding cultural diversity in business communication is Edward T. Hall's (1976) distinction of low-context and high-context cultures. It explains much about how negotiation is done, how agreements are specified, and how employees are managed. Still this distinction as insightful as it is derivative. It is best understood as reflecting a more essential distinction between principle-based and relationship-based cultures, which is in turn grounded in numerous conceptions of human nature.

\section{Employee Religion strategy and Organization Performance}

Religion is the high levels of traditional religious belief, frequent involvement in religious institutions such as churches, synagogues, mosques, and temples, and engagement in religious practices such as 
INTERNATIONAL JOURNAL OF ACADEMIC RESEARCH IN BUSINESS AND SOCIAL SCIENCES Vol. 8, No. 12, Dec, 2018, E-ISSN: 2222-6990 @ 2018 HRMARS

reading scripture, worship, and prayer (McCullough and Willoughby, 2009). Religion comprises of both religious belief and religious behavior. Religious belief, which is also referred to as internal religiosity, or faith, is defines as belief in God and a trusting acceptance of God's will (Steiner,et al., 2010). Religious behavior, or external religiosity, on the other hand, includes all observable activities, which are undertaken in a religious context, in particular going to church (Steiner,et al., 2010). Religion has been acknowledged as one of the significant elements that manipulate an individual's value system and hence in branding the cultural environment of an organization (Kutcher, et al., 2010). As mentioned by Abdel-Khalek, (2010) religion affects the way in which people behave through an individual's value system.

Cash and Gray (2000) examined that religion and spirituality strongly influence many American managers' behaviors' at work. Religion too was found to contribute to healthy organizations (Noland, 2003). For a long time the relationship between religion and work had been described as that, that cannot and should not be mixed (Noland, 2003). However, that has drastically changed. Individuals' are now increasing desiring to incorporate their religious perspective into their work and to express their religious and spiritual beliefs at work, (Barro, and McCleary 2003). There is a wealth of information that suggests a positive relationship between religiosity and subjective well-being (Abdel-Khalek, 2010). The positive consequences that studies show accompanies religious belief and practices have made the Americans to increasingly want their 10 religion integrated into all the areas of their lives (Kutcher, et al., 2010). The many benefits religious beliefs has been found to have on physical and mental health and ethical decision making, has pushed some organizations to support and encourage expressions of religion and faith in the workplace says Kutcher, et al., (2010).

Employees who are allowed to express their faith, religion, or spirituality improve the quality of work life, certainly for themselves, if not for others (Miller 2007). As Elm (2003) states, there is growing evidence that the line between workplace and religious beliefs is growing thin by the day. People differ in their religious motivation. Mecheo (2016) reveals that some people hold religious beliefs and engage in religious practices because they find their primary motivation in religion; their religious belief is driven by intrinsic factors. Others, however, see religious belief as a means to their own ends, such as a satisfying social need, a sense of security, and status (Allport and Ross, 1967). Their religious belief is driven by extrinsic factors. Weaver and Agle (2002) found that individuals with intrinsic religious orientation are high in determination and self-esteem thus encouraged and anticipated actual entrepreneurial activity. On the other hand, persons with extrinsic religious orientations appear to discourage entrepreneurship.

Morgan (2005) in his research has found that the traditional wall between faith and work is crumbling at an accelerated rate and that religion can longer seem to be "a hat that can be taken away and forgotten immediately an employee enters the doorway of an office." Further, Cash and Gray (2000) found that during the decade spanning 1994 to 2000 the percent of workers who felt they needed to experience spiritual growth in their work increased from $30 \%$ to $78 \%$. Because of these dramatic changes, organizational researchers have started examining the influence religion and spirituality have on work outcomes. Recent researchers have examined the relationship between religious belief and job satisfaction, job performance, organization-based self-esteem, and organizational frustration 
(Mecheo, 2016).

However, researchers have failed to examine the direct influence of individuals' religious and spiritual beliefs on their commitment to their work as well as their performance which influences the organization performance. Religious involvement can be defines as, the extent to which an individual attends religious services and takes part in worship activities, groups, committees, and worshiprelated organizations (Day, 2005). Researchers have examined the relationship between religiosity and civic involvement and found out that the more religious individuals easily took part in civic volunteer activities in the society (Weaver, and Agle, 2002). Day (2005) says that individuals with higher levels of religious involvement have lower rates of alcohol and drug abuse and addiction which have negative impacts on an employee's productivity. Noland (2003) adds that the relationship between religious practices and the avoidance or moderate use of alcohol is well documented, whether or not denominational groups specifically prohibit the use of alcohol. Barro and McCleary (2005) indicate that religion significantly affects the level of an individual's happiness and overall sense of wellbeing.

Happy people tend to be productive and law-abiding and also tend to learn well, thus having a positive impact on an organization's performance (Elm, 2003). Weaver, and Agle, (2002) state that employees who frequently attend religious services are less stressed, and have a greater sense of control which is correlated with decreased distress hence are more productive at work. They further add that the employees who have a strong religious commitment have an increased self-esteem and social support, as well as enhanced coping skills which positively contribute to their work performance. An earlier review of 250 epidemiological health research studies found a reduced risk of colitis, diverse types of cancer, and untimely death among people with higher levels of religious commitment.

Conversely, at any age, those who never attended religious programmes had higher risks of dying from cirrhosis of the liver, emphysema, arteriosclerosis, and other cardiovascular diseases and were more likely to commit suicide, according to an even earlier review by faculty of the John Hopkins University School of Public Health. Weaver and Agle (2002) add that the most significant pathway by which religious practice delivers these longevity benefits is a lifestyle that reduces the risk of mortality from infectious diseases and diabetes, by encouraging a support network among family and friends that helps to maintain a pattern of regimented care.

King and Williamson (2005) agree that healthy employees are more productive at work and they contribute tremendously to an organization's success. Conscientiousness, agreeableness, and satisfaction were all found to be positively associated with religion (Kutcher, et al., 2010; McCullough and Willoughby, 2003). Studies also found that Christian university students and adults during their important religious experience, perceived themselves as high in agreeableness and conscientiousness (McCullough and Willoughby, 2009). However, later studies have revealed that the relationship between individuals' religiousness and their involvement in civic organizations is more complicated than first believed (Day, 2005). Barro and McCleary (2003) have shown that, on average, 
it is true that the religious are more involved in civic organizations than the non-religious up to a certain level; but, as religiousness increases, religious involvement also increases leading to individuals spending less time engaged in secular, civic organizations. Individuals who are highly religious often devote a significant amount of their time and resources to their religious activities leaving little time for secular and civic activities. This then affects the organization's commitments and performance (Elm, 2003).

Day (2005) states that as an individual's religiosity increases, they become more devoted to their religious social networks which then weaken ties to other civic activities and organizations as well as coworkers. Garcia-Zamor (2003) explains that as religiosity in an individual increases, they begin to place more emphasis on their spiritual world and less emphasis on the material, secular world. The need to engage more in religious good works surpasses the desire to volunteer in civic activities (King, and Williamson, 2005). Noland (2003) adds that individuals who possess high levels of religiosity are more likely to place significant value on spiritual rewards than material rewards. This then may result to less attachment to financial or otherwise results offered by ones job. When this is the case, an organization faces a high employee turnover from the highly religious employees than from the nonreligious ones (Cash and Gray, 2000).

\section{Empirical Review}

Abdel (2012) examined the effects of cross cultural work force diversity on employee performance in Egyptian pharmaceutical organizations. The study explored the impact of gender, age, and education background on the performance of employee in the Egyptian Pharmaceutical industry which is renowned to employ highly diversified labor force. The study used a sample 300 middle level management positions. Data were collected via self-administered questionnaires methodology. The results revealed that only gender and education background are the two variables that were significant in explaining the discrepancy in workers performance when different work force work together, while surprisingly, age diversity does not.

Alharbi and Alyahya (2013) examined the impact of organizational culture on employee performance. Literature review was adopted as method for assessing the culture of an organization impacts upon process, employees and systems. Findings of the study showed that certain scope of culture has been recognized so far and research revealed that value and norms of an organization were based on employee relationship. The goal of an organization is to boost level of performance by designing strategies. The performance management system has been measured by balance scorecard and by understanding nature and ability of system culture of an organization have been identified.

Richard and Frank (2012) carried out a research titled a cross-cultural study of managerial skills and effectiveness; new insights or back to basics, to examine the relationship between managerial skills and effectiveness in a cross-cultural setting to determine their applicability.

Data from 7,606 managers in 5 countries from large multinational firms were analyzed using structural equation modeling to asses all relationships simultaneously and reduce error effects. The results are in concurrence with the cross cultural validity of the model of managerial skillseffectiveness. There few cross-cultural differences discovered in the results of the study, it was also found that interactive skills had greater positive impact on attitudes than initiating skill. While 
INTERNATIONAL JOURNAL OF ACADEMIC RESEARCH IN BUSINESS AND SOCIAL SCIENCES

Vol. 8, No. 12, Dec, 2018, E-ISSN: 2222-6990 C 2018 HRMARS

pressuring skills had a negative impact on attitudes, and none of the skill sets were related to job performance.

\section{METHODOLOGY}

\section{Research Design}

This study adopts a descriptive survey method to generate primary data through questionnaire and interview.

\section{Sources of Data}

Two types of data were collected for this study. The primary data were obtained from the selected multinationals in South East Nigeria, these includes; MTN Nigeria, Guinness Nigeria, Stanbic IBTC bank, Uniliver Nigeria Plc and DHL logistics while secondary data used in this study was sourced from relevant stock of literature on the subject matter of this study. This stock of literature exists in form of books, government documents, journals, periodicals, mimeographs, and reports etc.

\section{Population of the Study}

The study population consist 1,939 staff of the selected multinational companies in South East Nigeria listed in the table below:

Table 3.1: Population Distribution

\begin{tabular}{|l|c|}
\hline ORGANISATION & POPULATION \\
\hline MTN & 504 \\
\hline Guinness & 315 \\
\hline Stanbic IBTC bank & 643 \\
\hline Uniliver & 477 \\
\hline Total & $\mathbf{1 9 3 9}$ \\
\hline
\end{tabular}

Source: Operations Departments of the Government Support Agencies, 2015

\section{Determination of Sample Size}

Since the population of the study is finite; the sample was also determined using the formula by

$$
=\mathrm{Z}^{2} \mathrm{Npq}
$$

$$
\mathrm{Ne}^{2}+\mathrm{Npq}
$$

$\mathrm{n}=$ sample size

$\mathrm{N}=$ Population of the Study

$\mathrm{P}=$ Probability of Success

$Q=$ Probability of Failure

$Z=$ Standard error of mean

$\mathrm{e}=$ significant level

$\mathrm{e}=0.05$

$\mathrm{n}=$ ?

$\mathrm{N}=1939$ 
$p=0.6$

$q=0.4$

$\mathrm{Z}=1.96$

$n=\frac{(1.96)^{2} 1939(0.6)(0.4)}{1939(0.05)^{2}+(0.6)(0.4)}$

Hence the sample size for the study is 313

\section{Sampling Technique}

Proportionate stratified sampling method was adopted so as to give a proper representation to the multinationals in South East. A stratified sampling method was adopted so as to give a fair representation to the designated organizations. The Bowley's proportional allocation formula is given as:

$n h=\frac{n N h}{N}$

$\mathrm{nh}=$ Number of units allocated to each category

$\mathrm{Nh}=$ Number of items in each group

$\mathrm{n}=$ sample size

$\mathrm{N}=$ the total population size understudy

Thus

Number of units allocated to each category

MTN $\quad \underline{\mathrm{nh}=504 \times 310}=80.57$

1939

Guinness

$$
\frac{\mathrm{nh}=315 \times 310}{1939}=\underline{50.4}
$$

Uniliver

$$
\frac{\mathrm{nh}=477 \times 310}{1939}=79.3
$$

Stanbic IBTC bank $\underline{\mathrm{nh}=643 \times 310}=102.8$

1939

For check of accuracy thus: $\mathrm{n}_{\mathrm{h}}=\mathrm{n}$ 
INTERNATIONAL JOURNAL OF ACADEMIC RESEARCH IN BUSINESS AND SOCIAL SCIENCES Vol. 8, No. 12, Dec, 2018, E-ISSN: 2222-6990 @ 2018 HRMARS

Table 3.2: Sample Size Distribution

\begin{tabular}{lcc}
\hline Multinationals & Population & Total Sample Size \\
\hline MTN & 504 & 81 \\
Guinness & 315 & 50 \\
Stanbic IBTC bank & 643 & 103 \\
Uniliver & 477 & 79 \\
Total & 1939 & 313 \\
\hline
\end{tabular}

Source: Operations Departments of the Government Support Agencies, 2018

\section{Description of Instrument for Data Collection}

The major research instruments used in this study are: Questionnaire and Oral Interview. The questionnaire was designed to have two sections. All the questions in section [A] seek information about the respondent's personal data, while section [B] was formed directly to address the research objectives. The questionnaire contains 20 questions designed in 5-point Likert scale format. The interview questions were structured to obtain more information from the management of the various organisations under study. In all there are twenty one numbers of questions in the questionnaire

\section{Validity of the Research Instrument}

To ascertain the validity of the research instrument used in this study, the researcher ensured that the instruments measured the concepts they are supposed to measure by submitting a copy of the questionnaire to the supervisor and 2 experts in the field of cross culture management.

\section{Reliability of the Research Instrument}

To ensure reliability of the instrument, test-retest method of reliability was used in which 20 copies of the questionnaire were distributed to the selected multinationals; five (5) copies each to the five managers of the companies. Copies of the same instrument were redistributed after two weeks to the same respondents. The score from the two exercises were correlated using Cronbach's alpha approach. In carrying out the reliability of the research instrument, the Cronbach's Alpha was used. Cronbach's alpha $(\alpha)$ is an estimate of reliability, specifically the internal consistency, of test or scale. When the internal consistency is present in a test, it is interpretable (Cronbach, 1951) Cronbach's alpha seeks to measure how loosely test items are related to one another and thus measuring the same construct. In order to measure internal consistency of the instrument, Cronbach alpha was applied, which gave a reliability coefficient of $\alpha=0.923$ which indicate that the instrument is $92.3 \%$ reliable.

\section{Method of Data Analysis}

The completed questionnaire forms were collated, coded and subsequently analyzed using both descriptive and inferential statistics. In view of this, data obtained were presented in tables and percentages. The hypotheses were tested using linear regression analysis. These were done with the aid of Microsoft special package for social science (SPSS) version 20 at $5 \%$ level of significance. 
INTERNATIONAL JOURNAL OF ACADEMIC RESEARCH IN BUSINESS AND SOCIAL SCIENCES

Vol. 8, No. 12, Dec, 2018, E-ISSN: 2222-6990 C 2018 HRMARS

\section{TEST OF HYPOTHESES}

\section{Hypothesis one}

Ho: Cross-cultural communication strategy does not have any effect on employee performance of selected multinational companies in the South East of Nigeria

Table 4.1 Model Summary ${ }^{b}$

\begin{tabular}{|l|l|l|l|l|l|}
\hline $\begin{array}{l}\text { Mode } \\
\mathrm{I}\end{array}$ & $\mathrm{R}$ & R Square & $\begin{array}{l}\text { Adjusted } \mathrm{R} \\
\text { Square }\end{array}$ & $\begin{array}{l}\text { Std. Error of } \\
\text { the Estimate }\end{array}$ & $\begin{array}{l}\text { Durbin- } \\
\text { Watson }\end{array}$ \\
\hline 1 & $.930^{\mathrm{a}}$ & .865 & .864 & .44179 & .703 \\
\hline
\end{tabular}

a. Predictors: (Constant), cross-cultural communication strategy

b. Dependent Variable: employee performance

Table 4.2 ANOVA $^{a}$

\begin{tabular}{|ll|l|l|l|l|l|}
\hline \multicolumn{2}{|l|}{ Model } & $\begin{array}{l}\text { Sum of } \\
\text { Squares }\end{array}$ & Df & $\begin{array}{l}\text { Mean } \\
\text { Square }\end{array}$ & F & Sig. \\
\hline \multirow{2}{*}{1} & Regression & 287.703 & 1 & 287.703 & 1474.049 & $.000^{\mathrm{b}}$ \\
& Residual & 45.086 & 231 & .195 & & \\
& Total & 332.790 & 232 & & & \\
\hline
\end{tabular}

a. Dependent Variable: employee performance

Table 4.25 Coefficient

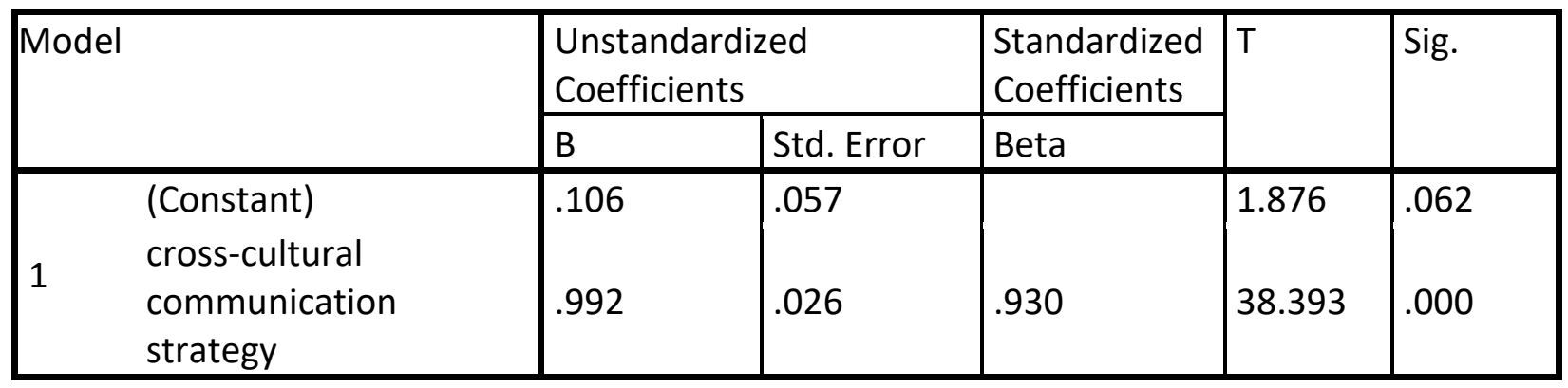

a. Dependent Variable: employee performance

\section{Result Summary}

$\mathrm{R}=.930 ; \mathrm{R}^{2}=.865 ; \quad \mathrm{F}=1474.049 ; \mathrm{T}=38.393 ; \mathrm{DW}=.703$

\section{Interpretation of the Result}

A linear regression analysis was conducted to ascertain the effect of adopting cross-cultural communication strategy on employee performance of selected multinational companies in the South East of Nigeria. The result shows that there is strong positive relationship between cross-cultural communication strategy and organizational employee performance ( $R$ - coefficient $=.930$ ). The $R$ square, the coefficient of determination, shows that $86.5 \%$ of the variation in employee performance can be explained by cross-cultural communication strategywith no autocorrelation as Durbin-Watson 
INTERNATIONAL JOURNAL OF ACADEMIC RESEARCH IN BUSINESS AND SOCIAL SCIENCES Vol. 8, No. 12, Dec, 2018, E-ISSN: 2222-6990 @ 2018 HRMARS

(.703) is less than 2. With the linear regression model, the error of estimate is low, with a value of about .44179. The regression sum of the square (287.703)is more than the residual sum of the square 45.086indicating that the variation is due to chance. The F-statistics $=1474.049$ shows that the model is significant. The extent to which cross-cultural communication strategy affect employee performance with .930 value indicates a positive significance between cross-cultural communication strategy and employee performance which is statistically significant (with $t=38.393$ ) and $p=.000<$ 0.05. Therefore, the null hypothesis is rejected and the alternate hypothesis accepted accordingly.

\section{Hypothesis Two}

Ho: Cross-cultural religious tolerance does not have any effect on employee performance of selected multinational companies in the South East of Nigeria

Table 4. 3 Model Summary

\begin{tabular}{|l|l|l|l|l|l|}
\hline $\begin{array}{l}\text { Mode } \\
\mathrm{I}\end{array}$ & $\mathrm{R}$ & R Square & $\begin{array}{l}\text { Adjusted } \mathrm{R} \\
\text { Square }\end{array}$ & $\begin{array}{l}\text { Std. Error of } \\
\text { the Estimate }\end{array}$ & $\begin{array}{l}\text { Durbin- } \\
\text { Watson }\end{array}$ \\
\hline 1 & $.738^{\mathrm{a}}$ & .545 & .543 & .94457 & .333 \\
\hline
\end{tabular}

a. Predictors: (Constant), cross-cultural religious tolerance

b. Dependent Variable: employee performance

Table 4.4 ANOVA ${ }^{\mathrm{a}}$

\begin{tabular}{|ll|l|l|l|l|l|}
\hline \multicolumn{2}{|l|}{ Model } & $\begin{array}{l}\text { Sum of } \\
\text { Squares }\end{array}$ & Df & $\begin{array}{l}\text { Mean } \\
\text { Square }\end{array}$ & F & Sig. \\
\hline \multirow{2}{*}{1} & Regression & 246.629 & 1 & 246.629 & 276.425 & $.000^{\mathrm{b}}$ \\
& Residual & 206.100 & 231 & .892 & & \\
& Total & 452.730 & 232 & & & \\
\hline
\end{tabular}

a. Dependent Variable: employee performance

b. Predictors: (Constant), cross-cultural religious tolerance

Table 4.28 Coefficients ${ }^{\mathrm{a}}$

\begin{tabular}{|c|c|c|c|c|c|c|}
\hline \multirow{2}{*}{\multicolumn{2}{|c|}{ Model }} & \multicolumn{2}{|c|}{$\begin{array}{l}\text { Unstandardized } \\
\text { Coefficients }\end{array}$} & $\begin{array}{l}\text { Standardized } \\
\text { Coefficients }\end{array}$ & \multirow[t]{2}{*}{$T$} & \multirow[t]{2}{*}{ Sig. } \\
\hline & & B & Std. Error & Beta & & \\
\hline \multirow[b]{2}{*}{1} & (Constant) & -.448 & .165 & & -2.714 & .007 \\
\hline & $\begin{array}{l}\text { cross-cultural religious } \\
\text { tolerance }\end{array}$ & .737 & .044 & .738 & 16.626 & .000 \\
\hline
\end{tabular}

a. Dependent Variable: employee performance

\section{Result Summary}

$R=.938 ; R^{2}=.545 ; \quad F=276.425 ; T=16.626 ; D W=.333$ 


\section{Interpretation of the Result}

A linear regression analysis was conducted to examine the effect of cross-cultural religious tolerance on employee performance of selected multinational companies in the South East of Nigeria. The result shows that there is strong positive relationship between cross-cultural religious tolerance and organizational employee performance $(R$ - coefficient $=.938)$. The $R$ square, the coefficient of determination, shows that $54.5 \%$ of the variation in employee performance can be explained by cross-cultural religious tolerance with no autocorrelation as Durbin-Watson (.333) is less than 2. With the linear regression model, the error of estimate is low, with a value of about.94457. The regression sum of the square 246.629 is more than the residual sum of the square 206.100indicating that the variation is due to chance. The F-statistics $=276.425$ shows that the model is significant. The extent to which cross-cultural religious tolerance affect employee performance with .938 value indicates a positive significance between cross-cultural religious tolerance and employee performance which is statistically significant (with $t=16.626$ ) and $p=.000<0.05$. Therefore, the null hypothesis is rejected and the alternate hypothesis accepted accordingly.

\section{Summary of Findings}

1. Cross cultural communication strategy positively affects employee performance of selected multinational companies in the South East of Nigeria $(r=.930 ; f=1474.049 ; t=38.393 ; p=$ .00)

2. Cross-cultural religious tolerance positively affects employee performance of selected multinational companies in the South East of Nigeria $(r=.938 ; f=276.425 ; t=16.626 ; p=.00)$.

\section{Conclusion}

Based on the summary of the findings, the following conclusion were drawn; the effect of crosscultural management on employees performance in selected multinationals in South East Nigeria, has encouraged organizational continue desire to engage in diversification, economics of scale, specialization, cost cutting, operational control, flexibility of staff, access to superior expertise, efficiency and effectiveness. Cross-cultural management is therefore the appropriate means by which organizations, especially multinationals could utilize in solving issues intensifying between individuals of organization in internal surroundings and in external atmosphere. Hence cross-cultural management is a renowned kind of management factoring in attempting to solve cultural dissimilarity between employees and management with analysis for improving communication and international interactions.

\section{Recommendations}

1. The management of various multinationals should develop a policy framework that will encourage the diverse cultural communication especially as regards to the operational area of the multinational.

2. The employees of an organization should see diverse religion within the organization as a tool for creating an atmosphere that will improve individual and organizational performance. 
INTERNATIONAL JOURNAL OF ACADEMIC RESEARCH IN BUSINESS AND SOCIAL SCIENCES

Vol. 8, No. 12, Dec, 2018, E-ISSN: 2222-6990 @ 2018 HRMARS

\section{References}

Ling, F. Y. Y. \& Lim, S. S. Y (2007), “Encounters between foreigners and Chinese: Perception and management of cultural differences". Engineering Construction \& Architectural Management (09699988); 2007, Vol. 14 Issue 6, p501-518, 18p.

Schmidt,W.V., Conaway, R.N., Easton, S. S., \& Wardrope, W. J. (2007), “Communicating Globally: Intercultural communication and International Business". Thousand Oaks, CA: Sage Publications.

Adair, D. (2001). “Credit Market Imperfections and Persistent Unemployment” European Economic Review.

Ihugba, O. A., Odii, A. and Njoku, A. C. (2013). Challenges and Prospects of Entrepreneurship in Nigeria. Academic Journal of Interdisciplinary Studies 2(5), 25.

Ihugba,O., Odii G., Njoku K.. (2011). Environmental Factors and Entrepreneurship Development in Nigeria, Journal of Sustainable Development in Africa (Vol 13, No.4, 2011)

Ihugba, O. A., Odii, A. and Njoku, A. C. (2013). Challenges and Prospects of Entrepreneurship in Nigeria. Academic Journal of Interdisciplinary Studies, 2(5), 25.

Abdel, M. (2012). The effects of cross cultural work force diversity on employee performance in Egyptian pharmaceutical organizations. Business and Management Research ISSN 1927-6001 (Print) ISSN 1927-601X (Online) accommodation theory approach. International Journal of Conflict Management, 13, 165-195.

Angel, U. (2017). Does Cross-Culture Human Resource Management Affect Performance of International Organizations? Evidence from Rwanda. International Journal of Innovation and Economic Development Volume 2, Issue 6, February 2017.

Barro, R. J., and McCleary, R. (2003). Religion and Economic Growth; National Bureau of Economic Research. No. w9682.

Cash, D. and Gray, B. (2000). “A Grounded Model of Organizational Schema Change during Empowerment". Organization Science, 11(2), pp. 235-257.

Day, D.V. (2005). Meta-analytic review of Leader-Member Exchange theory: Correlates and construct issues. Journal of Applied Psychology, 82(6): 827-844.

Edward, T. H. (1976). Beyond Culture. Garden City, NY; Anchor Books.

Elm (2003). A comparative study of the management styles of marketing managers in Australia and the People's Republic of China". International Marketing Review, 22(1), pp. 34-47.

Allport, G. and Ross, A. (1967). Managing across Cultures. London: Prentice Hall.

Hooker, J. (2008), Cultural Differences in Business Communication, Tepper School of Business, Carnegie Mellon University.

Kutcher, H. V., Härtel, C. E. and Callan, V. J. (2010). Resolving the puzzle of productive and metaanalysis of country differences in the high-performance work system-business

King, O. and Williamson, U. (2005). Integrated performance measurement: management accounting to support the new manufacturing realities." Journal of Management Accounting Research 4(Fall): 1-19.

McCullough, H. and Willoughby, N. (2009). Managing Cultural Differences: Values and Work Goals in Culture and Personality Contexts. Proceedings of the 10th International Conference Creativity \& Innovation: Imperatives for Global Business and Development, August 8-11, 
INTERNATIONAL JOURNAL OF ACADEMIC RESEARCH IN BUSINESS AND SOCIAL SCIENCES

Vol. 8, No. 12, Dec, 2018, E-ISSN: 2222-6990 @ 2018 HRMARS

Miller, D. (2007). Strategic Human Resource Management in Department Stores: A Historical Perspective. Journal of Retailing and Consumer Services,13(2).

Mecheo, K. (2016). The effect of Employee Cultural Diversity on Organizational performance: A case study of Oilybia-Kenya, United States International University.

Morgan, K. (2005). Information communication in organizations: form, function, and technology, in: R.M. Baecker (Ed.), Readings in Groupware and Computer-Supported Cooperative Work, Morgan Kaufmann Publishers, San Mateo, CA, pp. 287-314.

Noland, M. (2003). Religion, Culture, and Economic Performance. Institute for International Economics Working Paper.

Steiner, A., Dahl, O. and Stephan, D. (2010). Cross-cultural advertising research: What do we know about the influence of culture on advertising? Middlesex, U.K.: Middlesex University Discussion Paper No. 28. January.

Weaver, D. and Agle W. (2002). Managing Human Resources - Productivity, Quality of Work Life, Profits, Boston: McGraw Hill.

Cooper, R. and Denner, J. (1998). Theories Linking Culture and Psychology: Universal and Community-Specific Processes. Annual Review Psychology, 49.

Hodgetts and Luthans, F. (2003). International Management: Culture, Strategy, and Behavior. New York, McGraw-Hill/Irwin, Fifth Edition.

Hofstede, G. (1980). Motivation, Leadership, and Organization: Do American Theories Apply Abroad? Organizational Dynamics, 9(1).

Hofstede, G. (1984). Cultural Dimensions in Management and Planning. Asia Pacific Journal of Management, 1(2).

House, R., Javidan, M. and Dorfman, P. (2001). Project GLOBE: An Introduction. Applied Psychology: An International Review, 50(4).http://ideas.repec.org/p/cdl/indrel/qt2p 3880ms.html (October, 2017)

Kotter, J. P. and Heskett, J. L. (1992). Corporate culture and performance. New York: Free Press.

McClelland, D. C. (1973). IQ and personality tests are poor indicators of a person's competence, 28.

Robbins, S. P. and Sanghi, S. (2007). Organizational Behavior, Pearson Education, New Delhi.

Stewart, D. (2010). Growing the Corporate Culture, obtained from https://www.wachovia.com/foundation/v/index.jsp?vgnextoid=ab411f07760aa110VgnVCM $1000004 b 0 d 1872$ RCRD \& vgnextfmt=default on April, 23, 2012

Tichy, N. M. (1982). Managing Change Strategically: The Technical, Political, and Cultural Keys. Organizational Dynamics (autumn), pp. 59-80.

Torrington, D., Hall, L. (1998). Human Resource Management, 4thed. Hemel Hempstead: Prentice Hall Europe. [online]URL: <http://www.webstersonlinedictionary.org/definitions/multiculturalism $>$.

Trompenaars, F., and Charles, H. (1997). Riding the Waves of Culture, (2 ${ }^{\text {nd }}$ ed.). New York: McGrawHill.

Forehand, G. A. and Von Gilmer, (1964). Environmental Variations in Studies of Organizational Behavior. Psychological Bulletin, 62. 
INTERNATIONAL JOURNAL OF ACADEMIC RESEARCH IN BUSINESS AND SOCIAL SCIENCES

Vol. 8, No. 12, Dec, 2018, E-ISSN: 2222-6990 @ 2018 HRMARS

Richard, C., Frank, M., Jeanette, A., Dayton, O. and Denise, M. (2012). A cross-cultural study of managerial skills and effectiveness; new insights or back to basics?.www.emeraldinsight.com/1934-8835.htm

Alharbi, M. and Alyahya, M. (2013). Impact of Organizational Culture on Employee Performance. International review of management and business research. Volume 2. Issue 1. www.irmbrjournal.com 